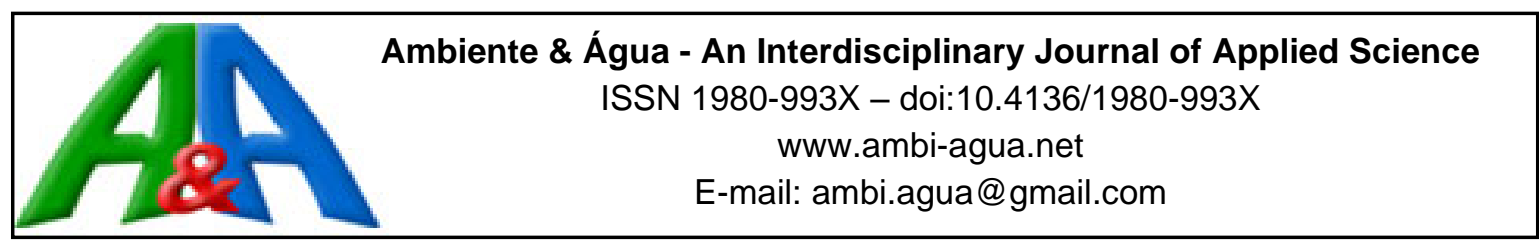

\title{
Cell damage in Danio rerio erythrocytes subjected to anthropized water
}

\author{
ARTICLES doi:10.4136/ambi-agua.2577
}

Received: 27 May 2020; Accepted: 03 Nov. 2020

\author{
Manoel Francisco Mendes Lassen ${ }^{1}$; Jefferson Frohlich² ${ }^{2}$; \\ Rodrigo Patera Barcelos ${ }^{3}$; Roberta Daniele Klein ${ }^{1}$; \\ Fernando Henrique Borba ${ }^{1 D}$; Suzymeire Baroni ${ }^{1 * i D}$
}

\begin{abstract}
${ }^{1}$ Programa de Pós-Graduação em Ambiente e Tecnologias Sustentáveis (PPGATS). Universidade Federal da Fronteira Sul (UFFS), Rua Major Antônio Cardoso, n 590, CEP: 97900-000, Cerro Largo, RS, Brazil. E-mail: manoellassen@gmail.com,roberta.klein@uffs.edu.br, fernando.borba@uffs.edu.br ${ }^{2}$ Departamento de Ciências Biológicas. Universidade Federal da Fronteira Sul (UFFS), Rua Major Antônio Cardoso, n 590, CEP: 97900-000, Cerro Largo, RS, Brazil. E-mail: frohlichjeffer@gmail.com ${ }^{3}$ Programa de Pós-Graduação em Biologia Comparada. Universidade Estadual de Maringá (UEM), Avenida Colombo, nº 5790, CEP: 87020-900, Maringá, PR, Brazil. E-mail: rodrigo.barcelos@uffs.edu.br

*Corresponding author. E-mail: suzymeire.baroni@uffs.edu.br
\end{abstract}

\begin{abstract}
Several factors can lead to alterations of water quality in aquatic environments, leading to numerous consequences for the organisms that inhabit it. The water bodies located in the northwest region of Rio Grande do Sul periodically receive pollutants that may have genotoxic, cytotoxic and mutagenic properties, which affect the genetic integrity of organisms living there. This research analyzed the cytological responses of Danio rerio exposed to anthropized fresh water from the Ijuí River by the micronucleus method as well as by observing nuclear abnormalities in their erythrocytes. The data collected demonstrated higher values of erythrocytes with NA than with $\mathrm{MN}$, suggesting that the cells are efficient in the repair mechanisms required when facing genotoxic substances.
\end{abstract}

Keywords: cytological responses, micronuclei, nuclear abnormalities.

\section{Danos celulares em eritrócitos Danio rerio submetidos à água antropizada}

\section{RESUMO}

Vários fatores podem levar a alterações da qualidade da água em ambientes aquáticos, levando a inúmeras consequências para os organismos que os habitam. Os corpos d'água localizados na região noroeste do Rio Grande do Sul recebem periodicamente poluentes que podem conter propriedades genotóxicas, citotóxicas e mutagênicas, que afetam a integridade genética dos organismos que ali vivem. Esta pesquisa teve como objetivo analisar as respostas citológicas de Danio rerio exposto à água doce antropizada do rio Ijuí pelo método do micronúcleo, bem como pela observação de anormalidades nucleares em seus eritrócitos. Os dados coletados demonstraram valores maiores de eritrócitos com NA do que com $\mathrm{MN}$, sugerindo que as células são eficientes nos mecanismos de reparo necessários ao enfrentamento de substâncias genotóxicas.

Palavras-chave: anormalidades nucleares, micronúcleos, respostas citológicas.

This is an Open Access article distributed under the terms of the Creative Commons Attribution License, which permits unrestricted use, distribution, and reproduction in any medium, provided the original work is properly cited. 


\section{INTRODUCTION}

The demographic census performed by the Brazilian Institute of Geography and Statistics (IBGE) indicates that the Brazilian population increased by approximately 20 times more in 2011 than in the year 1872. In the face of uncontrolled population growth, higher harvest rates are essential for meeting food demand.

Higher harvest rates are obtained through various methods, with the abusive use of pesticides being one of the most debated in the current decade. Use of pesticides in agriculture results in increased pesticide residues in food for human and animal consumption. These pesticides are a mixture of several compounds that consist of active substances which undergo biodegradation in soil and water (Czaja et al., 2020). Together with rain, the resulting substances can return to the soil, groundwater and surface water, where they undergo more transformations. These transformations continue in farm animals that are processed into food for human consumption.

Due to leaching, creeks and rivers located near large crop areas are one of the main destinations for pesticides, especially during rainy periods. According to Spadotto et al. (2004), leaching of pesticides tends to contaminate surface water and, in some cases, also groundwater. Therefore, these water resources are characterized as the final destination for some pesticides, which leads to contamination of springs (Kasper et al., 2018; Ramos et al., 2020).

Fish are commonly used organisms for biosensors in aquatic ecosystems, through the use of micronucleus (MN) analysis and nuclear abnormalities (NA) in their peripheral erythrocytes. The MN test is recognized as one of the preferred methods for assessing genetic damage in organisms, as it allows the detection of alterations caused by both clastogenic agents, responsible for chromosomal breakage, and aneugenic agents, which induce aneuploidy or chromosomal segregation abnormalities (Dalzochio et al., 2016; 2019; Ansari et al., 2011; Dearfield et al., 2002).

Danio rerio is a test organism popularly known as the zebrafish; it is a freshwater teleost, from the Cyprinidae Family, which reaches about three to four centimeters long as an adult. Danio rerio has attracted the attention of the scientific community as its management, breeding, reproduction, resistance and genetics are good parameters for use as a model organism (Barbazuk et al., 2000).

Danio rerio has been used as a model to test the action of pesticides in terms of genotoxicity, and these results have been extrapolated to the human genome (Hawkey et al., 2020). Thus, this study analyzed genotoxic data from Danio rerio placed in water samples from the referred anthropized points on the Ijui River (RS).

\section{MATERIAL AND METHODS}

\subsection{Period and sampling points}

Initially, four points on the Ijuí River were chosen for the collection of water to be used in the tests with Danio rerio.

The Ijuí River is located in the northwest region of Rio Grande do Sul State, between the coordinates $28^{\circ} 00^{\prime} \mathrm{S}$ to $29^{\circ} 05^{\prime} \mathrm{S}$ and $53^{\circ} 11^{\prime} \mathrm{W}$ to $55^{\circ} 21^{\prime} \mathrm{W}$ (Rio Grande do Sul, 2020), and begins with the confluence of the rivers Palmeira, Caxambu and Fiúza, near the municipality of Panambi (RS). It is the main river of the Ijuí Basin, which has an area of $10,703.78 \mathrm{~km}^{2}$ and is composed of 36 municipalities with various economic activities, including the presence of industries as well as extensive agricultural areas with high grain productivity. The basin consists of 12 more rivers that cut through cities and agricultural areas until they flow directly into the Ijuí River (Figure 1 and Table 1).

Rev. Ambient. Água vol. 16 n. 1, e2577 - Taubaté 2021 


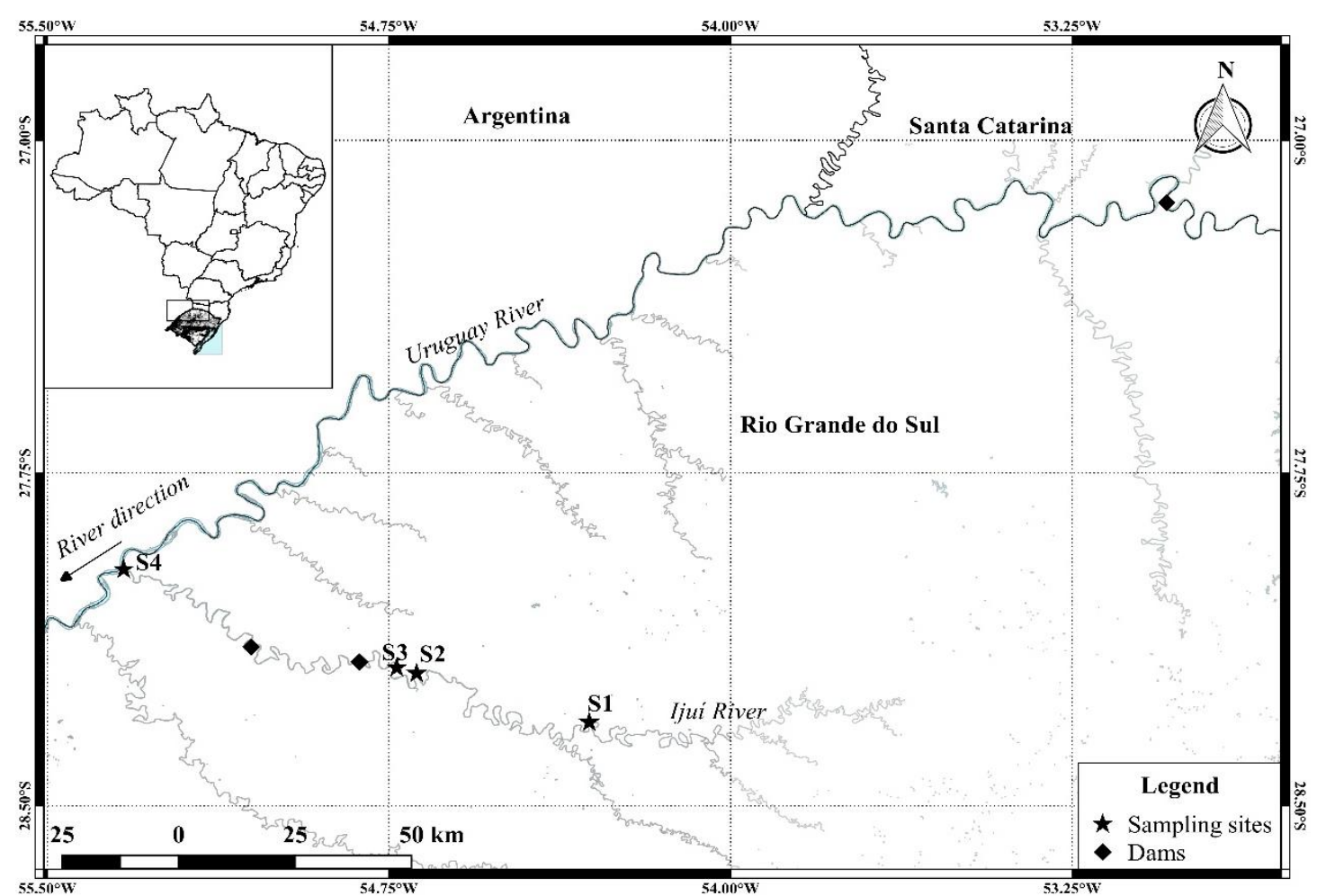

Figure 1. Location of the sampling points.

Source: Own construction, 2019.

Table 1. Coordinates of the water collection points on the Ijuí River with characteristics of their surrounding environments.

\begin{tabular}{|c|c|c|}
\hline Point (P) & Coordinates & Location Characteristics \\
\hline $\mathrm{P} 1$ & $\begin{array}{l}28^{\circ} 18 ' 50.74 " \mathrm{~S} \\
54^{\circ} 18,38.39^{\prime} " \mathrm{~W}\end{array}$ & $\begin{array}{l}\text { Absence of riparian forest and the reception of industrial and urban } \\
\text { effluents. }\end{array}$ \\
\hline $\mathrm{P} 2$ & $\begin{array}{l}28^{\circ} 11 ' 53.20^{\prime \prime} \mathrm{S} \\
54^{\circ} 41^{\prime} 25.47^{\prime \prime} \mathrm{W}\end{array}$ & $\begin{array}{l}\text { Absence of riparian forest, close to swine and livestock areas in addition to } \\
\text { extensive agricultural areas upstream. }\end{array}$ \\
\hline $\mathrm{P} 3$ & $\begin{array}{l}28^{\circ} 11 ' 19.26 " \mathrm{~S} \\
54^{\circ} 43^{\prime} 58.56^{\prime \prime} \mathrm{W}\end{array}$ & $\begin{array}{l}\text { Absence of riparian forest, with swine, livestock and agriculture areas. This } \\
\text { point is located at the São José Hydroelectric Dam - Ijuí Energia S.A,and is } \\
\text { therefore characterized as a lentic ecosystem. }\end{array}$ \\
\hline $\mathrm{P} 4$ & $\begin{array}{l}27^{\circ} 58^{\prime} 0.62^{\prime \prime} \mathrm{S} \\
55^{\circ} 19^{\prime} 57.82^{\prime \prime} \mathrm{W}\end{array}$ & $\begin{array}{l}\text { Absence of riparian forest and with great livestock activity. This point is } \\
\text { located at the mouth of the Ijuí River, which flows into the Uruguay River. }\end{array}$ \\
\hline
\end{tabular}

Sampling was carried out in a dry period. Danio rerio used in this research were obtained from a local aquarium at Cerro Largo, ten fish were used per test totaling 40 individuals. The fish were acclimatized for one week in aquariums with a capacity of 20 liters, 10 specimens per aquarium, in the Laboratory of Genetics and Molecular Biology of UFFS - Cerro Largo - RS. Following the acclimatization period, the $D$. rerio specimens were placed in the water collected from the four different points on the Ijuí River for $96 \mathrm{hrs}$. The fish were fed ad libitum under controlled temperature and Biochemical Oxygen Demand (BOD) conditions, as recommended by CONCEA Normative Resolution 34.

\subsection{Preparation of the blood films}

Following the $96 \mathrm{hr}$ period, the fish were sedated and euthanized according to the method approved by CEUA / n 589216051 through Eugenol. Blood was collected by puncture in the 
caudal artery using glass capillaries with EDTA (Ethylene Diaminetetraacetic Acid) for the preparation of blood smears. One slide was made per individual totaling ten slides per collection. The blood smear slides were dried at room temperature, fixed in methanol $(100 \%)$ for 20 minutes and stored for later staining.

\subsection{Staining of the blood films}

The methodology of MN slide confection followed Feulgen's protocol with Schiff staining and Fast-Green counterstaining.

The procedure comprised the following steps: (i) hydrolysis in $\mathrm{HCl}(5 \mathrm{~N})$ for five minutes; (ii) wash with distilled water; (iii) staining with Schiff reactive for two hours in the absence of light; (iv) wash with distilled water; (v) counterstaining with Fast-Green; (vi) wash with distilled water and (vii) drying.

\subsection{Erythrocyte count and observational analysis}

The observation and analysis of the slides were performed using an Olympus Optical Microscope with oil immersion lens (1000x maximum magnification). Three thousand cells per fish were counted and the presence of MN and NA were verified (Figure 1). The NA was classified into five groups according to the method of Carrasco et al. (1990) and Bebbled, Lobed, Notched, Vacuolated and Karyorrhexis by Ramirez (2000).

\subsection{Statistical Analysis}

The Kruskal-Wallis test for nonparametric data was chosen for analysis of the results, with a significance level of $5 \%(\mathrm{p}<0.05)$.

\section{RESULTS AND DISCUSSION}

No deaths or abnormal behaviors of the fish were observed during the testing period. The results were obtained through exposure of the zebrafish specimens to water collected at the sampling point in the Ijuí River and to clean control water.

The physicochemical parameters analysis of the collected water, as well as of the control water, is shown in Table 2. As can be verified in Table 2, the collected samples were not significantly different from the control according to the CONAMA Resolution 357/2005. The value for dissolved $\mathrm{O}_{2}$ in point 3 is well below that of the other collection points; however, this value was still within the parameters established by CONAMA. This low value for dissolved $\mathrm{O}_{2}$ is believed to be related to the fact that it is an area of lentic ecosystem, as shown in Table 1 .

Table 2. Physicochemical parameters of the aquarium water at the time of zebrafish euthanasia.

\begin{tabular}{lccccc}
\hline Parameter & Control & Point 1 & Point 2 & Point 3 & Point 4 \\
\hline $\mathrm{PH}$ & 8.42 & 8.2 & 7.74 & 7.9 & 7.3 \\
Conductivity $(\mu \mathrm{S})$ & 282 & 230 & 167.2 & 284 & 140.2 \\
Dissolved O2 $(\mathrm{mg} / \mathrm{L})$ & 9.9 & 9.7 & 5.1 & 11.3 & 12.8 \\
$\mathrm{H}_{2} \mathrm{O}$ Temperature $\left({ }^{\circ} \mathrm{C}\right)$ & 22.5 & 22.5 & 27.4 & 24.1 & 22 \\
Ambient & 24 & 24 & 28 & 20 & 24 \\
Temperature $\left({ }^{\circ} \mathrm{C}\right)$ & & & & & \\
\hline
\end{tabular}

Source: Own construction, 2019. 
The data for $\mathrm{MN}$ and NA, verified in 3,000 erythrocytes per fish kept in control and anthropized water, are presented in Figure 2.

As can be seen in Figure 2, the fish exposed to water from the four points on the Ijuí River demonstrated increased numbers of NA when compared to the fish subjected to control water. A slight increase in the development of NA was noticeable in the fish exposed to water from Point 2 that was statistically significant in relation to both the control group and Points 3 and 4 .

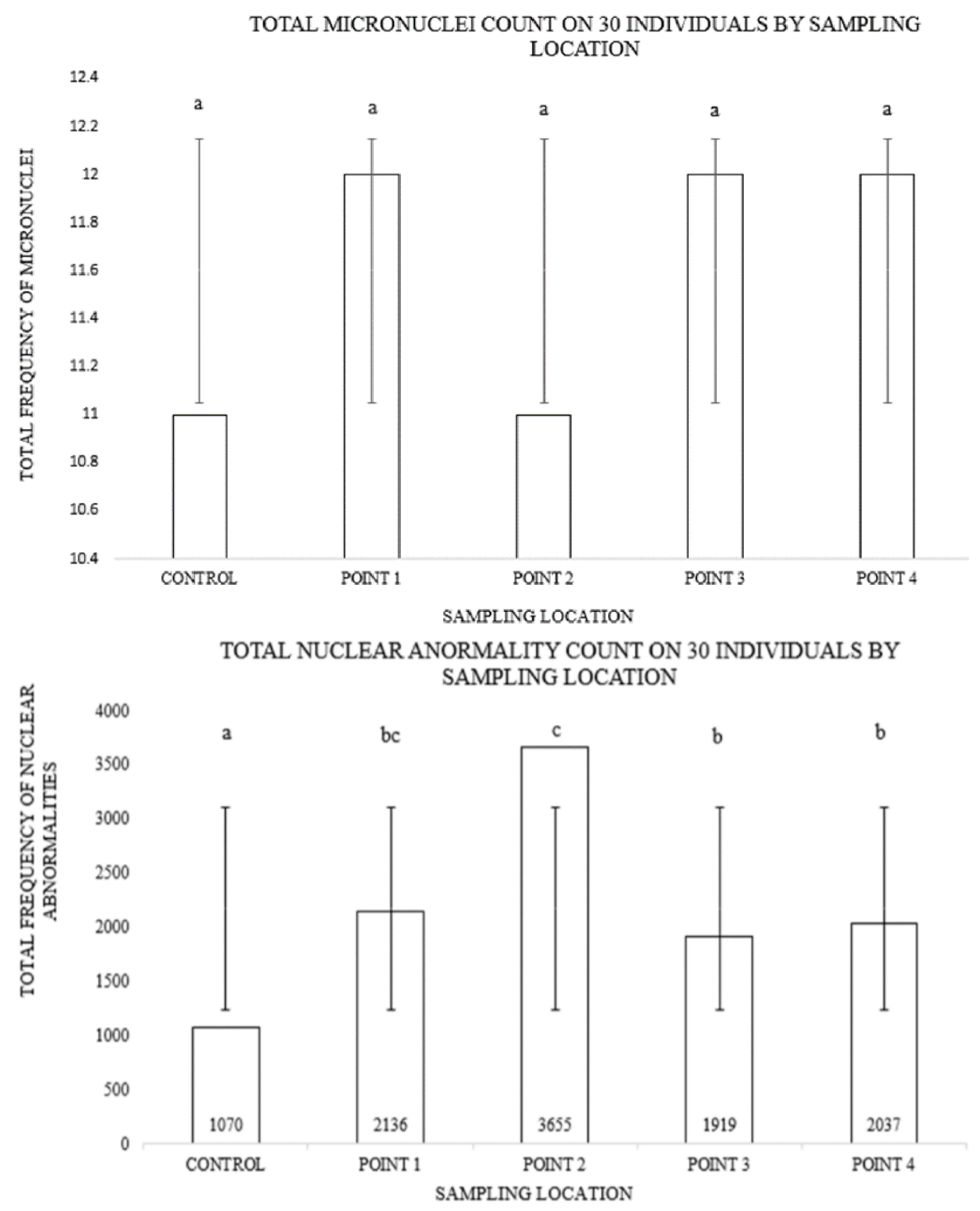

Figure 2. Absolute frequencies of micronuclei observed in 3,000 zebrafish erythrocytes (per aquarium), kept in control and anthropized fresh water. Values of MN and NA analyzed in 10 individuals of each test.

Source: Own construction, 2019.

Another important observation is that water from Point 3 had different characteristics from the other points as it was from a lentic ecosystem. However, this factor did not affect the final result of the NA number when compared to the other points with similar characteristics (Points 1 and 4).

The NA found in the analyzed erythrocytes are presented in Figure 3.

Industrial and agricultural effluents usually have clastogenic substances in their composition that can cause chromosomal breakage and dysfunctions of the mitotic spindles, resulting in the emergence of MN (Thomé et al., 2016). However, when applied to the KruskalWallis test, the MN values of the four test points were not statistically different from the control 
group, indicating that the water pollution of the Ijuí River does not cause genetic alterations at the level of $\mathrm{MN}$, which is characterized as damage that is no longer repairable.

The average emergence of $\mathrm{MN}$ in the tests was approximately one per 2,500-2,800 cells. According to Thomé et al. (2016), values less than or equal to $1 \mathrm{MN}$ per 1,000 cells are reported as an occurrence of endogenous origin in the organisms. The $\mathrm{MN}$ data were not statistically significant, however, the occurrence of this type of alteration is an event that cannot be repaired, thus the events that precede the establishment of $\mathrm{MN}$ are evidenced in the NA values, as shown in Table 2.

The MN test is simple to apply and enables the detection of genotoxic effects caused by several factors that organisms may be exposed to in their habitats (Alsabti and Mercalfe, 1995). However, MN can only be detected in extreme cases in which the repair system is unable to function. Additionally, this test detects damage from both clastogenic agents, responsible for chromosomal breaks, and aneugenic agents, which induce aneuploidy or abnormal chromosomal segregation (Ansari et al., 2011).

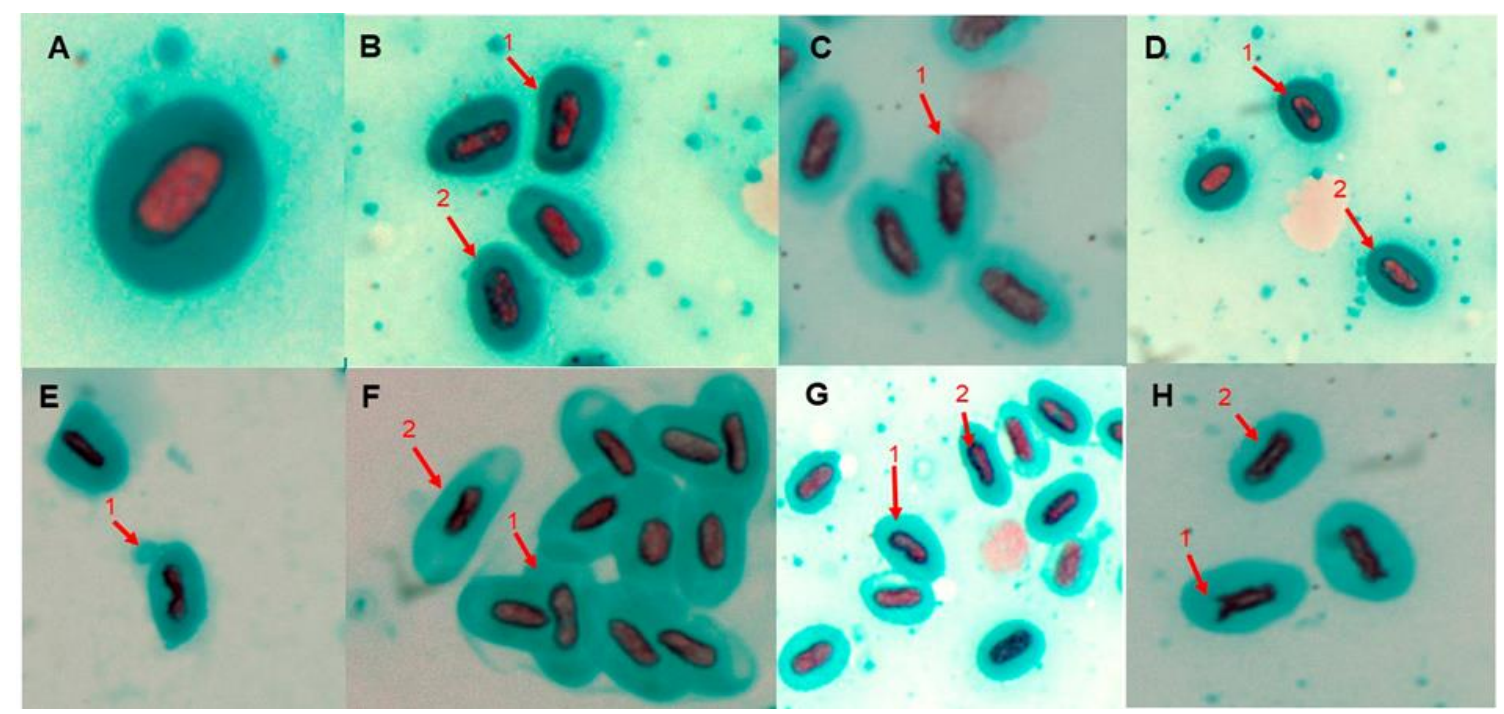

Figure 3. Images of the abnormalities found in blood erythrocytes of Danio rerio subjected to water collected from the four points on the Ijuí River.

Caption: (A) Normal erythrocyte; (B) 1- Notched; 2 - Karyorrhexis; (C) 1 - Chromosome detachment - Micronuclei; (D) 1 - Vacuolated; 2 - Karyorrhexis; (E) 1 - Lobbed; (F) 1 - Lobbed; 2 - Blebbed; (G) 1 - Notched; 2 - Blebbed; (H) 1 - Chromosomal detachment - Micronuclei; 2 Blebbed.

Source: Own construction, 2019.

Thus, this protocol has the potential to analyze events that precede the emergence of MN. However, it should be noted that compounds capable of interacting with DNA are not restricted exclusively to the effects of mutagenic substances, as there are genotoxic substances that, in addition to interacting with genetic material, also have the ability to interact with other cellular components, such as spindle fibers during cell division as well as cell enzymes, such as topoisomerase, causing nuclear changes.

It is worth noting the difference in the number of abnormalities seen between Points 2 and 3 , since these points are located in the same municipality and have the shortest distance between them. According to Thomé et al. (2016), rivers have a self-purification capacity, meaning that, when anthropic effluents are discharged, rivers and other watercourses have the ability to restore their natural characteristics in an attempt to promote self-purification.

Several characteristics may interfere in the self-purification of a river, including the average depth, watercourse speed, width and dissolved oxygen concentration. Furthermore, 
within a watercourse, it is possible to have segmentation in the self-purification zones; that is to say that, in the course there are variations between clean waters, which precede the effluent discharge zone, and a new stretch of water recovery after this point, where dissolved oxygen is introduced into the aquatic ecosystem and, soon after, the clean water zone arises again (Von Sperling and Chernicharo, 2005). Thus, it can be suggested that clastogenic substances present in Point 2 may not be carried to Point 3.

Considering that several species of fish have fundamental importance for both human ingestion and food chains, they are widely used as bioindicators. Moreover, the fact that fish respond very quickly to contamination exposure, even in small concentrations (similar to mammals), makes $D$. rerio an excellent laboratory model for studying the clastogenic potential of effluents resulting from anthropic activities (Thomé et al., 2016).

\section{CONCLUSIONS}

The anthropized water from the Ijuí River collected from all four of the analyzed points demonstrated the potential to induce clastogenic events in a zebrafish model. The data collected demonstrated higher values of erythrocytes with NA than with MN, suggesting that the cells are efficient in the repair mechanisms required when facing genotoxic substances.

\section{REFERENCES}

AL-SABTI, K.; MERCALFE, C. D. Fish micronuclei for assessing genotoxicity in water. Mutation research, v. 343, p. 121 135, 1995. https://doi.org/10.1016/01651218(95)90078-0

ANSARI, R. A.; RAHMAN, S.; KAUR, M.; ANJUM, S.; RAISUDDIN, S. In vivo cytogenetic and oxidative stress-inducing effects of cypermethrin in freshwater fish, Channa punctata Bloch. Ecotoxicology and Environmental Safety, v. 74, p. 50-156, 2011. https://doi.org/10.1016/j.ecoenv.2010.08.036

BARBAZUK, W. B.; KORF, I.; KADAVI, C.; HEYEN, J.; TATE, S.; WUN, E.; BEDELL, J. A.; MCPHERSON, J. D.; JOHNSON, S. L. The syntenic relationship of the zebrafish and human genomes. Genome research, v. 10, n. 9, p. 1351-1358, 2000. https://dx.doi.org/10.1101/gr.144700

CARRASCO, K.R.; TILBURY, K. L.; MAYERS, M. S. Assessment of the piscine micronuclei test in situ biological indicator of chemical contaminants effects. Canadian Journal of Fisheries and Aquatic Science, v. 47, p. 2123-2136, 1990. https://doi.org/10.1139/f90237

CZAJA, K.; STRUCINSKI P.; KORCZ, W.; MINORCZYK, M.; HEMIK, A.; WIADROWSKA, B. Alternative toxicological methods for establishing residue definitions applied for dietary risk assessment of pesticides in the European Union. Food and Chemical Toxicology, v. 137, 2020. https://doi.org/10.1016/j.fct.2020.111120

DALZOCHIO, T.; RODRIGUES, G. Z. P.; PETRY, I. E.; GEHLEN, G.; SILVA, L. B. Use of biomarkers to assess the health of aquatic exosystem in Brazil: a review. International Aquatic Research, v. 8, n. 4, p. 283-98, 2016. https://doi.org/10.1007/s40071-016-01479

DALZOCHIO, T.; SOUZA, M. S.; SIMÕES, L. A. R.; SILVA, G. J. H.; RODRIGUES, G. Z. P.; ANDRIGUETI, N. B.; SILVA, L. B. Impact of Anthropogenic activities on water quality of the Paranhana River, Southern Brazil. Brazilian Archives of Biology and Technology, v. 62, 2019. http://dx.doi.org/10.1590/1678-4324-2019180523 
DEARFIELD, L. K.; CIMINO, N. C.; MAUER, I.; VALCOVIC, L. R. Genotoxicity risk assessment: a proposed classification strategy. Mutation Research/Genetic Toxicology

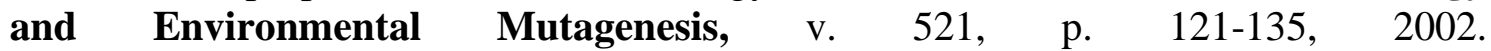
https://doi.org/10.1016/S1383-5718(02)00236-X

HAWKEY, A. B.; GLAZER, L.; DEAN, C. et al. Adult exposure to insecticides causes persistent behavioral and neurochemical alterations in zebrafish. Neurotoxicology and Teratology, 2020. https://doi.org/10.1016/j.ntt.2019.106853

KASPER, N.; BARCELOS, R. P.; MATTOS, M.; BARONI, S. Impact of anthropic activities on eukaryotic cells in cytotoxic test. Revistaa Ambiente \& Água, v. 13, n. 3, p. 1-10, 2018. https://doi.org/10.4136/ambi-agua.2107

RAMIREZ, A. Análise de células metanucleadas de alcoólicos portadores de carcinomas orais. 2000. 56f. Dissertação (Mestrado em Biologia) - Universidade de São Paulo, São Paulo, 2000.

RAMOS, L. P. N.; LEITE, D. M.; OLIVEIRA, A. S. L.; FARIAS, C. B. M.; DAHMER, N.; KARSBURG, I. V. Evaluation of the cytotoxic and genotoxic effect of Allium cepa L. (Amaryllidaceae) root cells after exposure in water samples of five lakes of Alta Floresta, State of Mato Grosso. Revista Ambiente \& Água, v. 15, n. 1, 2020. https://doi.org/10.4136/ambi-agua.2463

RIO GRANDE DO SUL. Secretária do Meio Ambiente e Infraestrutura. U090 - Bacia Hidrográfica do Rio Ijuí. Available at: https://www.sema.rs.gov.br/u090-baciahidrografica-do-rio-ijui. Access: 25 Jan. 2020.

SPADOTTO, C. A. et al. Monitoramento do risco ambiental de agrotóxicos: princípios e recomendações. Jaguariúna: Embrapa Meio Ambiente, 2004. 29p.

THOMÉ, R. G.; SILVA, P. M.; SANTOS, H. B. Avaliação de genotoxidade da água de um rio urbano utilizando estudo de células sanguíneas de Danio rerio. Conexão Ciência (Online), v. 11, n. 2, p. 9-16, 2016.

VON SPERLING, M.; CHERNICHARO, C. A. L. Biological wastewater treatment in warm climate regions. London: IWA publishing, 2005. 810p. Vol. 1. 